Tersedia online di: http://ejournal-balitbang.kkp.go.id/index.php/jra

\title{
PERFORMA IKAN PATIN HIBRIDA PASUPATI (PANGASIID) DARI INDUK TERSELEKSI PADA SISTEM BUDIDAYA BERBEDA
}

\author{
Evi Tahapari", Jadmiko Darmawan, Ika Nurlaela, Wahyu Pamungkas, dan Huria Marnis \\ Balai Penelitian Pemuliaan Ikan
}

\begin{abstract}
ABSTRAK
Pada segmen pembenihan, ikan patin Pasupati II hasil hibridisasi antara ikan patin Siam betina dan ikan patin Jambal jantan menunjukkan performa terbaik dibandingkan ikan patin Pasupati l, dan patin Siam F-1. Penelitian ini bertujuan untuk menguji performa ikan patin Pasupati II pada segmen pembesaran yang dilakukan di kolam air tenang (KAT) berukuran $50 \mathrm{~m}^{2}$, dan di jaring (berukuran $5 \mathrm{~m}$ x $3 \mathrm{~m}$ x 1,5 m) yang dipasang di tambak air payau (TAP, salinitas $<10 \mathrm{ppt}$ ). Ikan uji yang digunakan adalah ikan patin Pasupati II, Pasupati I, dan patin Siam F-1 dengan bobot awal di KAT 11,1-16,1 g/ekor, dan di TAP 21,3-32,5 g/ekor. Sebanyak dua KAT, dan dua jaring di TAP digunakan untuk setiap kelompok ikan. Parameter yang diamati meliputi: pertambahan bobot dan panjang harian, konversi pakan, sintasan, kualitas air pemeliharaan, dan konsentrasi hormon Insuline-like Growth Factor (IGF-I) pada plasma darah. Hasil penelitian menunjukkan bahwa performa ikan patin Siam F-1 pada parameter pertambahan bobot memberikan yang terbaik $(\mathrm{P}<0,05)$ dibandingkan patin Pasupati I dan II yang dipelihara di KAT dan di TAP. Kemudian performa pertambahan bobot ikan patin Pasupati II lebih baik $(\mathrm{P}<0,05)$ daripada patin Pasupati I yang dipelihara di TAP. Hasil analisis ELISA pada beberapa ikan uji yang dipelihara di KAT menunjukkan bahwa konsentrasi hormon IGF1 tertinggi terdapat pada ikan patin siam F-1 $(4,48 \pm 0,81 \mathrm{ng} / \mathrm{mL})$, kemudian diikuti oleh patin Pasupati II $(3,96 \pm 0,51 \mathrm{ng} / \mathrm{mL})$; dan terendah pada ikan patin Pasupati I $(3,93 \pm 0,54 \mathrm{ng} / \mathrm{mL})$. Jika dicermati dari data pertumbuhan dan konsentrasi hormon IGF-1 ikan uji ternyata terdapat korelasi yang positif antara pertumbuhan ikan dengan konsentrasi hormon IGF-1, semakin tinggi tingkat pertumbuhan ikan maka semakin tinggi konsentrasi hormon IGF-1 pada ikan uji.
\end{abstract}

KATA KUNCI: performa; hibridisasi; Pasupati ll; pembesaran

ABSTRACT: Performance of catfish hybrid pasupati (pangasiid) from the selected parent stock reared in different culture system. By: Evi Tahapari, Jadmiko Darmawan, Ika Nurlaela, Wahyu Pamungkas, and Huria Marnis

In thenursery, Pasupati II catfish hybrid offemale Siamese catfish and male Jambal catfish showed the best performance compared to Pasupati I catfish and Siam catfish F-1 generation. The aim of this study was to test performance of Pasupati II on grow out segment in freshwater pond (KAT) measure $50 \mathrm{~m}^{2}$ and in net cage (measure $3 \mathrm{~m} \times 5 \mathrm{~m} \times 1.5$ m) which settled in brackishwater pond (TAP, salinity $<10$ ppt). The fish that used were Pasupati II, Pasupati I, and Siam catfish F-1 with body weight of 11.1-16.1 g/fish in KAT, and 21.3-32.5 g/fish in TAP. A total of two KAT, and two TAP were used for each group of fish. Parameters observed were included daily body weight and length, feed conversion ratio (FCR), survival rate, water quality, and concentration of insulin-like growth factor (IGF-1) hormone on plasma. The results showed that the performance of Siamese catfish F-1 growth parameters give the best weight gain $(P<0.05)$ than catfish Pasupati I and II were maintained at KAT and TAP. Then the weight gain performance catfish Pasupati II was better $(P<0.05)$ than that of catfish Pasupati I reared in TAP. Results of ELISA analysis on some of the fish that are reared in the KAT were showed that the concentration of the hormone IGF-1 was highest in F-1 Siamese catfish (4.48 $\pm 0.81 \mathrm{ng} / \mathrm{mL})$, followed by Pasupati catfish II $(3.96 \pm 0.51 \mathrm{ng} / \mathrm{mL})$ and the lowest in the Pasupati catfish I (3.93 \pm $0.54 \mathrm{ng} / \mathrm{mL}$ ). When the data of growth and IGF-1 hormone concentrations in the tested fish was examined there was a positive correlation, the higher the growth rate of the fish followed the higher concentration of the IGF-1 hormone in the test fish.

KEYWORDS: performance; hybridization; Pasupati II; grow out

\# Korespondensi: Balai Penelitian Pemuliaan Ikan

Jl. Raya 2 Pantura Sukamandi, Patokbeusi, Subang 41263,

Jawa Barat, Indonesia.

Tel.: + (0260) 520500

E-mail: evitahapari@yahoo.co.id 


\section{PENDAHULUAN}

Dalam rangka pengembangan usaha budidaya ikan patin untuk kebutuhan pasar ekspor diperlukan ikan patin dengan daging berwarna putih. Ciri ini dimiliki pada ikan patin Pasupati yang merupakan hasil persilangan antara induk betina patin Siam dengan induk jantan patin Jambal (F-0). Namun demikian performa ikan patin Pasupati masih harus terus diperbaiki dalam konteks peningkatan produksi dan produktivitas ikan nasional, salah satu aspek yang diperbaiki adalah pada karakter pertumbuhan. Strain ikan patin hasil perbaikan tersebut dinamakan ikan patin Pasupati II. Pembentukan ikan patin Pasupati II dilakukan melalui persilangan antara induk betina patin Siam dengan induk jantan patin Jambal hasil seleksi famili (F-1). Berdasarkan hasil riset sebelumnya pada kegiatan seleksi pembentukan induk unggul ikan patin Siam (F-1) diperoleh nilai kemajuan seleksi pada karakter bobot sebesar 9,47\% (Pamungkas et al., 2012) dan pada patin Jambal sebesar 15,7\% (Sularto et al., 2012). Keunggulan yang didapatkan pada nilai kemajuan seleksi pada induk ikan patin Siam dan ikan patin Jambal diharapkan dapat memberikan keunggulan pula pada hibridanya.

Penelitian ini merupakan rangkaian kegiatan program seleksi induk ikan patin Siam dan patin Jambal tahun sebelumnya. Hasil penelitian sebelumnya dilaporkan oleh Tahapari et al. (2014) bahwa penggunaan induk ikan hasil seleksi (induk Siam F-1 dan Jambal F-1) dan perlakuan hibridisasi dapat meningkatkan performa benih hibridanya (Pasupati II) dibandingkan dengan benih patin Pasupati I dan Siam F-1. Performa benih ikan patin Pasupati II pada segmen pendederan l yang dipelihara secara indoor selama 28 hari menunjukkan percepatan pertambahan bobot dan panjang masing-masing sebesar $11,17 \%$ dan $10,16 \%$ lebih tinggi terhadap benih ikan patin Siam F-1; serta $4,34 \%$ dan 7,06\% lebih tinggi daripada benih ikan patin Pasupati I. Namun demikian terhadap parameter reproduksi (derajat fertilisasi, derajat tetas telur, abnormalitas larva) dan sintasan tidak memberikan perbedaan yang nyata $(\mathrm{P}>0,05)$ antar populasi. Kemudian pada segmen pendederan 2, performa ikan patin Pasupati II memberikan percepatan pertambahan bobot $54,17 \%$ dan percepatan pertambahan panjang $18,18 \%$ terhadap patin Siam F-1, serta memberikan percepatan pertambahan bobot $27,91 \%$ dan percepatan pertambahan panjang $8,33 \%$ terhadap patin Pasupati I.

Insulin-like growth factor I (IGF-I) merupakan hormon mitogenik yang dapat merangsang pertumbuhan dan diferensiasi organ tertentu (Butler \& LeRoith, 2001). IGF-I bersirkulasi terikat dengan sejumlah protein IGF-binding (IGFBPs), yang dapat merangsang pertumbuhan (Pierce et al., 2005). Biasanya, GH disekresikan dari kelenjar hipofisis, beredar dalam plasma, dan mengikat reseptor hormon pertumbuhan (GHR) untuk merangsang transkripsi mRNA IGF-I dan selanjutnya protein IGF-I dilepaskan dari hati dan jaringan-jaringan lainnya (Shimizu et al., 1999).

Informasi keragaan budidaya patin Pasupati II pada segmen pembesaran belum diketahui dengan pasti, untuk itu, perlu dilakukan penelitian terkait performa budidaya di berbagai sentra pembesaran ikan patin. Pada penelitian ini dilakukan pembesaran di kolam air tawar (KAT) dan tambak air payau (TAP; salinitas $<10$ ppt). Penelitian ini bertujuan untuk mengevaluasi keragaan pertambahan bobot, panjang, konversi pakan, sintasan, dan konsentrasi hormon IGF-I pada beberapa populasi ikan patin yang dipelihara pada segmen pembesaran.

\section{BAHAN DAN METODE}

\section{Wadah Ikan Uji}

Wadah yang digunakan untuk pemeliharaan ikan uji adalah tambak air payau (TAP, salinitas $<10 \mathrm{ppt}$ ) dengan menggunakan enam buah jaring ukuran $3 \mathrm{~m} \mathrm{x}$ $5 \mathrm{~m}$ x 1,5 m; dan pemeliharaan di kolam air tenang (KAT) menggunakan enam buah kolam masing-masing berukuran $50 \mathrm{~m}^{2}$ dengan kedalaman air sekitar $1 \mathrm{~m}$.

\section{Ikan Uji}

Penelitian ini merupakan kelanjutan dari riset sebelumnya. Ikan patin Pasupati II adalah benih hasil persilangan antara induk betina patin Siam F-1 dengan induk jantan patin Jambal F-1 hasil seleksi famili. Metode seleksi yang digunakan adalah seleksi dalam famili (within family selection) (Tave, 1995). Sebagai benih pembanding adalah benih ikan patin Siam F-1 (o Siam F-1 $><\sigma^{*} \quad$ Siam F-1) dan patin Pasupati I (o Siam F-0 $><\sigma^{*}$ Jambal F-0). Benih ikan uji merupakan hasil pemijahan buatan secara berpasangan menggunakan induk berukuran 3-4 kg/ekor dengan masing-masing ikan uji betina sebanyak dua ekor dan jantan dua ekor. Benih ikan uji yang digunakan mempunyai bobot dan panjang awal masing-masing sebesar 11,1-16,1 g dan 9,3-10,0 cm untuk pemeliharaan di KAT, dan untuk di TAP 21,3-32,5 g dan 10,9-12,8 cm.

Ikan uji didapatkan dari pemijahan dengan persilangan seperti di atas melalui pemijahan buatan dengan menggunakan hormon HCG dan ovaprim (Tahapari et al., 2007). HCG disuntikkan pada induk betina dengan dosis $500 \mathrm{IU} / \mathrm{kg}$ ikan, sedangkan ovaprim disuntikkan dengan dosis $0,6 \mathrm{~mL} / \mathrm{kg}$ untuk induk betina, dan $0,2 \mathrm{~mL} / \mathrm{kg}$ untuk induk jantan. 


\section{Pakan Ikan Uji}

Pakan pembesaran yang digunakan adalah pakan komersial dengan kadar protein kasar sebesar 28\%$30 \%$. Pakan diberikan dengan feeding rate 3\%-5\% dan frekuensi tiga kali per hari.

\section{Parameter Uji}

Parameter yang diamati adalah pertambahan bobot dan panjang harian, konversi pakan, sintasan, dan kadar hormon insuline-like growth factor-1 (IGF-I) pada plasma darah ikan patin. Sampling bobot dan panjang ikan dilakukan setiap satu bulan sekali dan sekaligus dilakukan jumlah penyesuaian pakan yang diberikan berdasarkan biomassa ikan.

Pada akhir penelitian dilakukan pengamatan terhadap rata-rata bobot, sintasan, dan konversi pakan. Pertambahan bobot harian (g/hari) ikan patin dihitung menggunakan rumus (Castell \& Tiews, 1980):

$$
\mathrm{a}=\frac{\text { bobot } \mathrm{akhir}(\mathrm{g}) \text { - bobot awal }(\mathrm{g})}{\text { waktu pemeliharaan (hari) }}
$$

Konversi pakan dihitung menggunakan rumus (NRC, 1977):

$$
\mathrm{FCR}=\frac{\mathrm{Wp}}{(\mathrm{Wt}+\mathrm{D})-\mathrm{Wo}}
$$

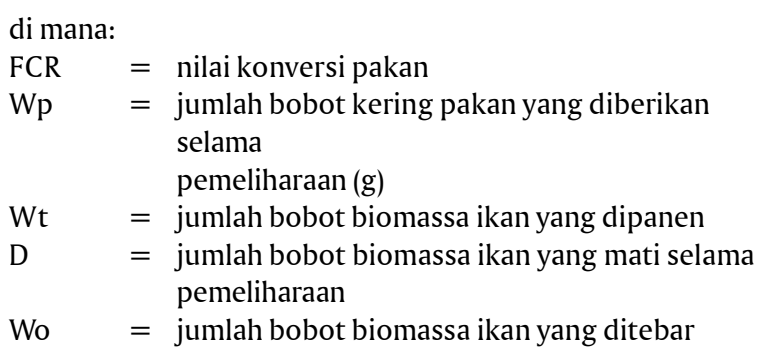

Konsentrasi hormon IGF-1 diukur menggunakan metode ELISA (Enzyme Linked Immunosorbent assay) dengan kit hormon IGF-I (DRG diagnostic, USA) sesuai dengan petunjuk penggunaan. Pengukuran hormon IGF-I menggunakan masing-masing sembilan sampel plasma ikan patin Siam F-1, patin Pasupati I dan patin Pasupati II, di mana semua sampel diuji duplo. Pengambilan darah pada ikan patin yang dipelihara di kolam air tawar (KAT) dilakukan pada akhir pemeliharaan. Sebelumnya ikan dibius dengan menggunakan MSS (Tricain mesylate) dengan konsentrasi $0,8 \mathrm{~g} / \mathrm{L}$.

Pengamatan kualitas air terhadap parameter $\mathrm{pH}$, oksigen terlarut (DO), suhu, turbiditas, dan konduktivitas dilakukan secara in-situ, sedangkan untuk parameter amonia dan nitrit dilakukan secara in-vitro (Metode SNI 06-6989-30-2005, SNI 06-6989-9-2004 Spektrofotometri).

Tabel 1. Performa tiga populasi ikan patin yang dipelihara di kolam air tenang (KAT)

Table 1. The performance of the three populations of catfish that were kept in freshwater concrete

\begin{tabular}{|c|c|c|c|}
\hline \multirow{2}{*}{$\begin{array}{l}\text { Parameter } \\
\text { Parameters }\end{array}$} & \multicolumn{3}{|c|}{ Perlakuan (Treatments) } \\
\hline & Siam F-1 & Pasupati I & Pasupati II \\
\hline Bobot awal (Initial body weight) (g) & $14.2 \pm 7.3^{\mathrm{a}}$ & $11.1 \pm 1.9^{\mathrm{a}}$ & $16.1 \pm 3.0^{\mathrm{a}}$ \\
\hline Bobot akhir (Final body weight) (g) & $634 \pm 49^{\mathrm{a}}$ & $508 \pm 27^{b}$ & $524 \pm 68^{b}$ \\
\hline $\begin{array}{l}\text { Pertambahan bobot harian (g/hari) } \\
\text { Daily weight gain (g/day) }\end{array}$ & $3.44 \pm 0.27^{\mathrm{a}}$ & $2.76 \pm 0.15^{\mathrm{b}}$ & $2.82 \pm 0.38^{\mathrm{b}}$ \\
\hline Panjang standar awal (Initial standard length) $(\mathrm{cm})$ & $9.4 \pm 1.3^{\mathrm{a}}$ & $9.3 \pm 0.5^{\mathrm{a}}$ & $10.0 \pm 0.8^{\mathrm{a}}$ \\
\hline Panjang standar akhir (Final standard length) $(\mathrm{cm})$ & $33.0 \pm 0.7^{\mathrm{a}}$ & $31.4 \pm 0.5^{\mathrm{a}}$ & $31.0 \pm 1.1^{\mathrm{a}}$ \\
\hline $\begin{array}{l}\text { Pertambahan panjang standar harian (cm/hari) } \\
\text { Daily standard length gain (cm/day) }\end{array}$ & $0.13 \pm 0.00^{\mathrm{a}}$ & $0.12 \pm 0.00^{\mathrm{a}}$ & $0.12 \pm 0.01^{\mathrm{a}}$ \\
\hline Panjang total awal (Initial total length) $(\mathrm{cm})$ & $11.5 \pm 1.6^{\mathrm{a}}$ & $11.3 \pm 0.6^{\mathrm{a}}$ & $12.2 \pm 0.8^{\mathrm{a}}$ \\
\hline Panjang total akhir (Final total length) $(\mathrm{cm})$ & $40.6 \pm 0.3^{\mathrm{a}}$ & $39.2 \pm 0.6^{\mathrm{a}}$ & $39.0 \pm 1.2^{\mathrm{a}}$ \\
\hline $\begin{array}{l}\text { Pertambahan panjang total harian (cm/hari) } \\
\text { Daily total length gain (cm/day) }\end{array}$ & $0.16 \pm 0.00^{\mathrm{a}}$ & $0.16 \pm 0.00^{\mathrm{a}}$ & $0.15 \pm 0.01^{\mathrm{a}}$ \\
\hline Sintasan (Survival rate) (\%) & $97.20 \pm 0.00^{\mathrm{a}}$ & $91.30 \pm 10.00^{\mathrm{a}}$ & $48.2 \pm 3.1^{\mathrm{b}}$ \\
\hline Konversi pakan (Feed convertion ratio ) & $1.3 \pm 0.0^{\mathrm{a}}$ & $1.5 \pm 0.2^{\mathrm{a}}$ & $3.0 \pm 0.2^{\mathrm{b}}$ \\
\hline
\end{tabular}
pond 


\section{Analisis Data}

Analisis data menggunakan sidik ragam pada selang kepercayaan 95\%. Jika dari hasil perhitungan diketahui berbeda nyata, maka dilanjutkan dengan Uji Beda Nyata Terkecil (Uji BNT) dengan selang kepercayaan 95\% (Steel $\&$ Torrie, 1981).

\section{HASIL DAN BAHASAN}

Hasil pengamatan pada beberapa populasi ikan uji (patin Pasupati II, Pasupati I, dan Siam F-1) yang dipelihara di KAT menunjukkan keragaan pertambahan bobot yang signifikan $(\mathrm{P}<0,05)$, sebagaimana ditampilkan pada Tabel 1. Demikian juga pemeliharaan yang dilakukan di TAP menunjukkan performa budidaya yang relatif baik pada tiga populasi ikan patin sebagaimana ditampilkan pada Tabel 2 .

Dari Tabel 1 dan 2 diketahui bahwa pertambahan bobot harian $(\mathrm{PBH})$ populasi ikan patin Siam F-1 di KAT dan di TAP adalah tertinggi $(\mathrm{P}<0,05)$ dibandingkan ikan patin Pasupati I dan Pasupati II. Kemudian PBH ikan patin Pasupati II dan Pasupati I adalah sama $(\mathrm{P}>0,05)$ di KAT. Sedangkan di TAP, PBH ikan patin Pasupati II lebih tinggi daripada patin Pasupati I $(\mathrm{P}<0,05)$. Hasil penelitian ini tidak sesuai dengan pola pertumbuhan yang terjadi pada segmen pendederan 1 dan 2, di mana ikan patin Pasupati II memberikan performa yang terbaik $(\mathrm{P}<0,05)$ dibandingkan ikan patin Pasupati I dan Siam F-1 (Tahapari et al., 2014). Performa atau penampilan individu ditentukan oleh dua faktor, yaitu faktor genetik dan faktor lingkungan. Pengaruh faktor genetik bersifat baka, sedangkan faktor lingkungan bergantung pada kapan dan di mana individu berada (Hardjosubroto, 1994). Faktor yang berpengaruh terhadap performa pada segmen pembesaran ini diduga karena pengaruh lingkungan budidaya yang tidak sesuai dengan kebutuhan tumbuh optimal ikan patin Pasupati II dan I. Salah satu aspek lingkungan yang berpengaruh adalah kualitas air pemeliharaan. Hasil pengamatan parameter kualitas air penelitian di KAT dan TAP tertera pada Tabel 3 dan 4. Dari beberapa parameter kualitas air yang diamati bahwa kadar oksigen terlarut (DO) menunjukkan nilai yang ekstrim pada pagi hari sampai dengan $0,1 \mathrm{mg} / \mathrm{L}$ di KAT dan 2,2 mg/L di TAP. Oksigen terlarut (dissolved oxygen/DO) merupakan faktor yang sangat penting bagi kehidupan organisme perairan. Faktor ini selalu menjadi faktor pembatas utama dalam kolam budidaya. Kelarutan oksigen dalam air digunakan untuk respirasi organisme dan dekomposisi bahan organik dalam perairan. Kelarutan oksigen diperoleh dari difusi air dan hasil fotosintesis. Kadar oksigen terlarut yang sesuai bagi organisme perairan adalah $5-8 \mathrm{mg} / \mathrm{L}$ (Boyd, 1990). Dari segi ekosistem, kadar oksigen terlarut

Tabel 2. Performa tiga populasi ikan patin yang dipelihara di tambak air payau (TAP)

Table 2. The performance of the three populations of catfish that were reared in brackishwater pond

\begin{tabular}{|c|c|c|c|}
\hline \multirow{2}{*}{$\begin{array}{l}\text { Parameter } \\
\text { Parameters }\end{array}$} & \multicolumn{3}{|c|}{ Perlakuan (Treatments) } \\
\hline & Siam F-1 & Pasupati I & Pasupati II \\
\hline Bobot awal (Initial body weight) (g) & $32.5 \pm 7.3^{\mathrm{a}}$ & $21.3 \pm 9.1^{\mathrm{a}}$ & $23.2 \pm 3.7^{\mathrm{a}}$ \\
\hline Bobot akhir (Final body weight) (g) & $964 \pm 15^{a}$ & $474 \pm 128^{c}$ & $657 \pm 127^{b}$ \\
\hline $\begin{array}{l}\text { Pertambahan bobot harian (g/hari) } \\
\text { Daily weight gain (g/day) }\end{array}$ & $5.18 \pm 0.08^{\mathrm{a}}$ & $2.51 \pm 0.71^{c}$ & $3.52 \pm 0.70^{\mathrm{b}}$ \\
\hline Panjang standar awal (Initial standard length) $(\mathrm{cm})$ & $10.9 \pm 1.5^{\mathrm{a}}$ & $11.5 \pm 0.5^{\mathrm{a}}$ & $12.8 \pm 0.9^{\mathrm{a}}$ \\
\hline Panjang standar akhir (Final standard length) $(\mathrm{cm})$ & $37.7 \pm 0.4^{\mathrm{a}}$ & $30.5 \pm 1.8^{\mathrm{a}}$ & $43.8 \pm 0.8^{\mathrm{a}}$ \\
\hline $\begin{array}{l}\text { Pertambahan panjang standar harian (cm/hari) } \\
\text { Daily standard length gain (cm/day) }\end{array}$ & $0.14 \pm 0.00^{\mathrm{a}}$ & $0.11 \pm 0.01^{\mathrm{b}}$ & $0.12 \pm 0.00^{\mathrm{b}}$ \\
\hline Panjang total awal (Initial total length) $(\mathrm{cm})$ & $13.5 \pm 1.7^{\mathrm{a}}$ & $14.3 \pm 0.7^{\mathrm{a}}$ & $15.9 \pm 1.2^{\mathrm{a}}$ \\
\hline Panjang total akhir (Final total length) $(\mathrm{cm})$ & $46.2 \pm 0.3^{\mathrm{a}}$ & $38.3 \pm 2.7^{\mathrm{b}}$ & $42.7 \pm 1.4^{\mathrm{b}}$ \\
\hline $\begin{array}{l}\text { Pertambahan panjang total harian (cm/hari) } \\
\text { Daily total length gain }(\mathrm{cm} / \text { day) }\end{array}$ & $0.17 \pm 0.00^{\mathrm{a}}$ & $0.14 \pm 0.02^{b}$ & $0.16 \pm 0.01^{\mathrm{a}}$ \\
\hline Sintasan (Survival rate ) $(\%)$ & $97.67 \pm 0.47^{\mathrm{a}}$ & $90.67 \pm 13.20^{\mathrm{a}}$ & $97.0 \pm 4.24^{\mathrm{a}}$ \\
\hline Konversi pakan (Feed convertion ratio ) & $1.9 \pm 0.1^{\mathrm{a}}$ & $2.1 \pm 0.1^{\mathrm{a}}$ & $2.1 \pm 0.4^{\mathrm{a}}$ \\
\hline $\begin{array}{ll}\text { an (Note): } & \text { Data disajikan dalam bentuk rera } \\
& \text { yang berbeda pada lajur yang sa } \\
& \text { standard deviation. Different supersc } \\
& (P<0.05))\end{array}$ & $\begin{array}{l}\text { standar dev } \\
\text { lenunjukkan }\end{array}$ & $\begin{array}{l}\text { Vilai yang diikt } \\
\text { berbeda nyata }\end{array}$ & $\begin{array}{l}\text { uruf superskrip } \\
0,05) \text { (Mean } \pm \\
\text { nt difference }\end{array}$ \\
\hline
\end{tabular}


akan menentukan kecepatan metabolisme dan respirasi dari keseluruhan ekosistem. Selain sebagai penentu tingkat metabolisme ekosistem perairan tersebut, kadar oksigen sangat penting bagi kelangsungan dan pertumbuhan biota air. Kondisi kadar oksigen terlarut yang rendah ini tentunya sangat tidak mendukung untuk pertumbuhan optimal dalam budidaya ikan patin. BSN (2000) memberikan persyaratan kadar DO pada budidaya ikan patin harus lebih dari $4 \mathrm{mg} / \mathrm{L}$. Dari ketiga populasi ikan patin yang dipelihara (Siam, Pasupati I, Pasupati II) menunjukkan bahwa rendahnya kadar DO perairan relatif tidak berpengaruh terhadap pertumbuhan ikan patin Siam namun berbeda pada ikan patin Pasupati I dan Pasupati II. Performa populasi ikan patin Siam menunjukkan yang terbaik $(\mathrm{P}<0,05)$ dibandingkan dengan ikan patin Pasupati I dan Pasupati II yang dipelihara di KAT maupun di TAP. Menurut Browman \& Kramer (1985); Levefre et al. (2011) bahwa ikan patin Siam memiliki gelembung renang yang dapat digunakan sebagai alat pernapasan tambahan untuk langsung mengambil gas oksigen dari udara, sehingga kadar DO yang rendah ini masih dapat ditoleransi oleh ikan patin Siam. Sebaliknya, kondisi ini diduga tidak dapat ditoleransi oleh ikan patin Pasupati I dan II yang merupakan produk hibrida betina patin Siam dengan jantan patin Jambal sehingga berpengaruh negatif terhadap pertumbuhan optimal ikan. Kajian ini sangat menarik untuk diteliti lebih lanjut. Sementara ini belum ada hasil penelitian yang melaporkan bahwa ikan patin Pasupati dapat langsung mengambil oksigen dari udara sebagaimana kemampuan yang dimiliki ikan patin Siam.

Ikan patin Pasupati merupakan ikan hasil hibridisasi antara betina patin Siam dengan jantan patin Jambal. Hibridisasi merupakan program perbaikan genetis melalui persilangan untuk mengembangkan stok (populasi) genetis baru bagi perikanan budidaya yang diterapkan ketika hanya terdapat sedikit atau tidak ada keragaman genetis aditif dari suatu karakter tertentu yang dapat dieksploitasi (dikembangkan) pada populasi populasi murni melalui program seleksi (Gjedrem, 1993; Tave, 1995). Hibridisasi dilakukan melalui persilangan antara dua populasi ikan (induk tetua) menghasilkan suatu populasi ikan baru (hibrida) yang memiliki keunggulan pada karakter karakter tertentu. Populasi ikan tetua yang disilangkan umumnya memiliki keunggulan pada karakter-karakter tertentu, sehingga melalui kombinasi yang tepat tersebut diharapkan populasi hibridanya akan memiliki keunggulan-keunggulan tersebut (memiliki heterosis atau hybrid vigor). Patin hibrida Pasupati dibentuk dengan tujuan utama untuk memiliki kualitas daging yang lebih baik dibandingkan ikan patin Siam, yakni berdaging putih menyerupai ikan patin Jambal (LRPTBPAT, 2006). Hasil penelitian yang dilaporkan oleh
Ariyanto \& Utami (2006) bahwa persilangan antara betina patin Jambal dengan jantan patin Siam berhasil meningkatkan nilai keragaman genetik karakter bobot dan panjang terhadap keturunan yang dihasilkan dengan nilai masing-masing sebesar 40,47 dan 13,55. Sedangkan persilangan antara betina patin Siam dengan jantan patin Jambal memberikan dampak yang sebaliknya, yaitu menurunkan nilai keragaman genetik karakter bobot dan panjang dengan nilai masin-masing sebesar 7,72 dan 2,32.

Heterosis ikan hibrida dengan karakteristik pertumbuhan yang lebih baik dari karakteristik (performansi) terbaik induk tetuanya merupakan heterosis yang sangat diharapkan dari suatu program hibridisasi. Namun demikian karakteristik pertumbuhan hibrida yang lebih baik dari nilai ratarata kedua induk tetuanya dapat dipertimbangkan sebagai suatu heterosis yang penting (Lutz, 2001). Iswanto (2011) melaporkan dari hasil penelitiannya bahwa karakteristik pertumbuhan ikan patin hibrida siam-nasutus berdasarkan pertambahan panjang total, panjang standar, dan bobot secara umum lebih baik daripada rata-rata tetuanya dan tidak berbeda nyata dari karakteristik terbaik induk tetuanya, sehingga dapat dikatakan memiliki heterosis karakter pertumbuhan yang nyata. Kemudian dari hasil penelitian yang dilaporkan oleh Gustiano \& Kristanto (2007) bahwa benih patin hasil hibridisasi secara resiprokal antara patin siam dengan patin Jambal memiliki karakteristik pertumbuhan yang lebih baik daripada induk-induknya.

Hibridisasi dilakukan untuk mengeksploitasi adanya efek heterosis dari kombinasi kedua induk tetuanya (Bakos, 2001; Bartley et al., 2001; Lutz, 2001; Fjalestad, 2005). Keunggulan karakteristik hibrida merupakan hasil dari suatu kombinasi yang tepat dan bisa saja bersifat tidak fertil (steril), kalaupun fertil maka akan menghasilkan keturunan dengan berbagai genotipe dan fenotipe karena kombinasi yang tepat tersebut tidak langsung terwariskan dan akan terpecah. Dengan demikian ikan hibrida merupakan produk akhir yang dibentuk pada setiap proses produksi (Bartley, 2005; Kapuscinski \& Miller, 2007). Pada umumnya ikan hibrida menampakkan karakter laju pertumbuhan di antara (intermediate) kedua induk tetuanya. Ikan tilapia hibrida hasil persilangan antara ikan nila Oreochromis niloticus dengan ikan mujair Oreochromis mosambicus memiliki laju pertumbuhan yang lebih baik dibandingkan ikan mujair, tetapi tidak lebih baik dibandingkan ikan nila (Sudarto, 1993; Thanakijkorn, 1997 dalam Pongthana, 2001). Demikian pula pada patin Pasupati hasil persilangan antara betina patin siam dengan jantan patin Jambal memiliki laju pertumbuhan yang relatif lebih tinggi dibandingkan 
patin siam, tetapi tidak lebih tinggi daripada patin Jambal pada segmen pembenihan (LRPTBPAT, 2006).

Populasi ikan patin Pasupati II yang dipelihara di TAP pada karakter bobot dan panjang total (Tabel 2) terlihat adanya peningkatan tumbuh dibandingkan dengan patin Pasupati I walaupun konsentrasi DO dalam air kolam pemeliharaan relatif rendah $(2,2 \mathrm{mg} /$ L) namun ikan Pasupati masih bisa menoleransi untuk tumbuh walau tidak maksimal. Pertumbuhan ini juga diduga karena penggunaan induk tetua hasil seleksi dan perlakuan hibridisasi sehingga dapat meningkatkan sifat unggul yang lebih baik. Kemudian performa karakter bobot dan panjang pada populasi ikan patin Pasupati I dan Pasupati II yang dipelihara di KAT tidak menunjukkan perbedaan yang nyata $(\mathrm{P}>0,05)$, hal ini diduga karena pengaruh lingkungan air pemeliharaan yang sangat ekstrem yaitu rendahnya kadar DO sampai dengan $0,1 \mathrm{mg} / \mathrm{L}$ di KAT, sehingga hal ini menjadi faktor pembatas pertumbuhan optimal ikan patin sehingga gen pembawa pertumbuhan (bobot) tidak dapat terekspresikan dengan maksimal. Namun pada pemeliharaan di TAP dengan kadar DO 2,2 mg/L yang relatif lebih tinggi dibandingkan dengan kadar DO di KAT meskipun masih di bawah kisaran kebutuhan optimal (> $4 \mathrm{mg} / \mathrm{L}$ ) diduga ikan uji masih dapat mengekspresikan gen pertumbuhannya sehingga ikan patin Pasupati II (yang dibentuk dari tetua hasil seleksi famili) memberikan performa lebih baik pada karakter bobot $(\mathrm{P}<0,05)$ dibandingkan dengan ikan patin Pasupati I. Gustiano \& Kristanto (2007) melaporkan bahwa patin hibrida hasil hibridisasi antara betina patin Siam dengan jantan patin Jambal pada segmen pembesaran memiliki nilai keragaan laju pertumbuhan yang lebih baik dibandingkan kedua induk tetuanya. Kemudian hasil penelitian yang dilaporkan oleh Iswanto \& Tahapari (2011) bahwa pada segmen pemeliharaan larva patin hibrida Siam-Jambal hanya memiliki heterosis yang positif terhadap patin Siam sebagai induk betinanya, tetapi memiliki heterosis yang negatif terhadap patin Jambal sebagai induk jantannya maupun terhadap nilai rata-rata patin Siam dan Jambal.

Menurut Gustiano et al. (2008), bahwa perbaikan mutu genetik untuk meningkatkan produksi dan produktivitas pada ikan dapat dilakukan dengan berbagai cara: pertama, dengan melakukan introduksi jenis unggul dari luar; kedua, melakukan persilangan/ hibridisasi; ketiga, memanfaatkan keunggulan jenis kelamin (pada ikan-ikan tertentu) dan keempat, melakukan seleksi terhadap karakter penting. Kemudian hasil penelitian sebelumnya terkait dengan penggunaan induk ikan hasil seleksi dilaporkan bahwa pada uji banding pertumbuhan antara ikan hasil seleksi dari penelitian yang dilakukan dengan ikan yang digunakan oleh pembudidaya ikan di kolam tanah didapatkan bahwa ikan hasil seleksi memiliki pertumbuhan 200\% lebih besar (Winarlin \& Gustiano, 2007). Demikian juga yang dilaporkan oleh Listyowati \& Ariyanto (2007) bahwa pertumbuhan ikan hasil seleksi dibandingkan dengan beberapa strain yang ada di masyarakat memperlihatkan pertumbuhan yang lebih cepat meskipun ukuran awal yang lebih kecil. Hasil penelitian ini juga sesuai dengan yang dilaporkan oleh Ariyanto \& Utami (2006) bahwa hibridisasi pada ikan patin Siam dan Jambal (pada pembentukan Pasupati l) memberikan pengaruh yang sangat nyata terhadap parameter bobot ikan, serta rata-rata laju pertumbuhan keturunan hasil persilangan lebih baik dibandingkan dengan tetuanya. Perolehan ikan hibrida sangat bergantung pada karakter dari induk tetua yang digunakan.

Aspek fertilitas reproduksi merupakan salah satu karakter yang dipertimbangkan dalam program hibridisasi. Hibridisasi juga dapat menghasilkan ikan hibrida yang steril secara langsung. Hibridisasi antara betina ikan karper rumput Ctenopharyngodon idella dengan jantan ikan Aristichthys nobilis menghasilkan ikan hibrida triploid yang steril (Sutton et al., 1981). Hasil pengamatan pada aspek reproduksi ikan patin Pasupati menunjukkan bahwa uji fertilisasi antara betina patin Pasupati dengan jantan patin Pasupati, patin Siam maupun patin Jambal pada penelitian ini tidak dapat dilakukan, karena oosit terovulasi patin Pasupati tidak dapat diperoleh. Persilangan balik melalui fertilisasi antara jantan patin Pasupati dengan betina patin Siam maupun patin Jambal menunjukkan bahwa karakteristik embrio, larva, dan benih yang dihasilkan serupa dengan karakteristik embrio, larva dan benih spesies-spesies patin induk betinanya, mengindikasikan adanya dominasi pengaruh maternal dan terjadinya ginogenesis. Hal tersebut juga mengindikasikan bahwa jantan patin Pasupati bersifat tidak fertil (steril) (Iswanto \& Tahapari, 2015). Penelitian-penelitian lebih lanjut diperlukan untuk memastikan hal tersebut.

Rata-rata ukuran morfometrik dan meristik dari ikan hibrida kebanyakan berada pada pertengahan (intermediate) di antara nilai rata-rata morfometrik dan meristik induknya. Hasil penelitian sebelumnya dilaporkan bahwa karakteristik morfometrik ikan patin hibrida hasil hibridisasi antara ikan patin Siam dengan ikan patin Jambal (Patin Pasupati) berdasarkan hasil analisis PCA (principal component analysis) lebih menyerupai ikan patin Siam (Gustiano \& Kristanto, 2007). Hasil yang serupa dilaporkan oleh Iswanto (2011) bahwa karakteristik meristik patin hibrida hasil hibridisasi antara betina patin Siam dengan jantan patin Nasutus lebih menyerupai patin siam sebagai induk 
betinanya dari pada patin Nasutus sebagai induk jantannya. Patin hibrida Pasupati memiliki jari-jari sirip perut sebanyak tujuh, sama dengan patin hibrida hasil hibridisasi antara betina patin Siam dengan jantan patin Nasutus (Gustiano \& Kristanto, 2007; Iswanto, 2011).

Dari Tabel 1 dan 2 diketahui bahwa sintasan dari ketiga populasi ikan patin uji yang dipelihara di TAP tidak berbeda nyata $(P>0,05)$, namun demikian jika dihitung secara biomassa saat panen terlihat adanya perbedaan yang signifikan, secara berturut-turut biomassa pada saat panen; ikan patin Siam F-1 141,23 kg; ikan patin Pasupati I 64,47 kg; dan ikan patin Pasupati II 95,59 kg. Kemudian nilai sintasan ikan uji yang dipelihara di KAT dari ketiga populasi menunjukkan perbedaan yang nyata $(P<0,05)$. Populasi ikan patin Pasupati II memiliki sintasan yang paling rendah dibandingkan dengan ikan patin Siam F-1 dan Pasupati I. Nilai sintasan yang rendah ini diduga karena adanya hama/predator. Hal ini dibuktikan dengan ditemukannya tiga ekor labi-labi yang berukuran 1-1,5 kg/ekor di kolam pemeliharaan ikan patin Pasupati II. Hama/predator ini sangat dimungkinkan memangsa benih patin pada saat berukuran benih sehingga sintasan menjadi rendah. Biomassa saat panen dari ketiga populasi ikan uji yang dipelihara di KAT adalah; ikan patin Siam $308,12 \mathrm{~kg}$; ikan patin Pasupati I 231,9 kg; dan ikan patin Pasupati II $126,28 \mathrm{~kg}$.

Nilai konversi pakan dari ketiga populasi ikan patin yang dipelihara di KAT maupun di tambak memberikan nilai yang relatif lebih tinggi jika dibandingkan dengan hasil penelitian yang dilaporkan oleh Tahapari (2013) bahwa kegiatan pembesaran ikan patin Siam dan patin Pasupati yang dilakukan di KAT dan tambak bersalinitas rendah (<10 ppt) memberikan nilai konversi pakan 1,24-1,41. Tingginya nilai konversi pakan pada penelitian ini, terutama pada populasi ikan patin Pasupati II yang dipelihara di KAT diduga akibat ada kesalahan dalam memprediksi jumlah ikan yang masih hidup di kolam sehingga pada saat penghitungan penyesuaian jumlah pakan di setiap bulannya berdasarkan sintasan ikan 100\% karena memang berdasarkan pengawasan/monitoring tidak terdapatnya ikan yang mati di kolam, kematian atau hilangnya ikan uji di kolam tidak dapat terdeteksi/tercatat. Sehingga jumlah pakan yang diberikan melebihi jumlah kebutuhan ikan yang sebenarnya. Pakan yang diberikan tidak semuanya termanfaatkan/dimakan oleh ikan. Nilai sintasan ikan dihitung pada akhir penelitian, saat ikan dipanen.

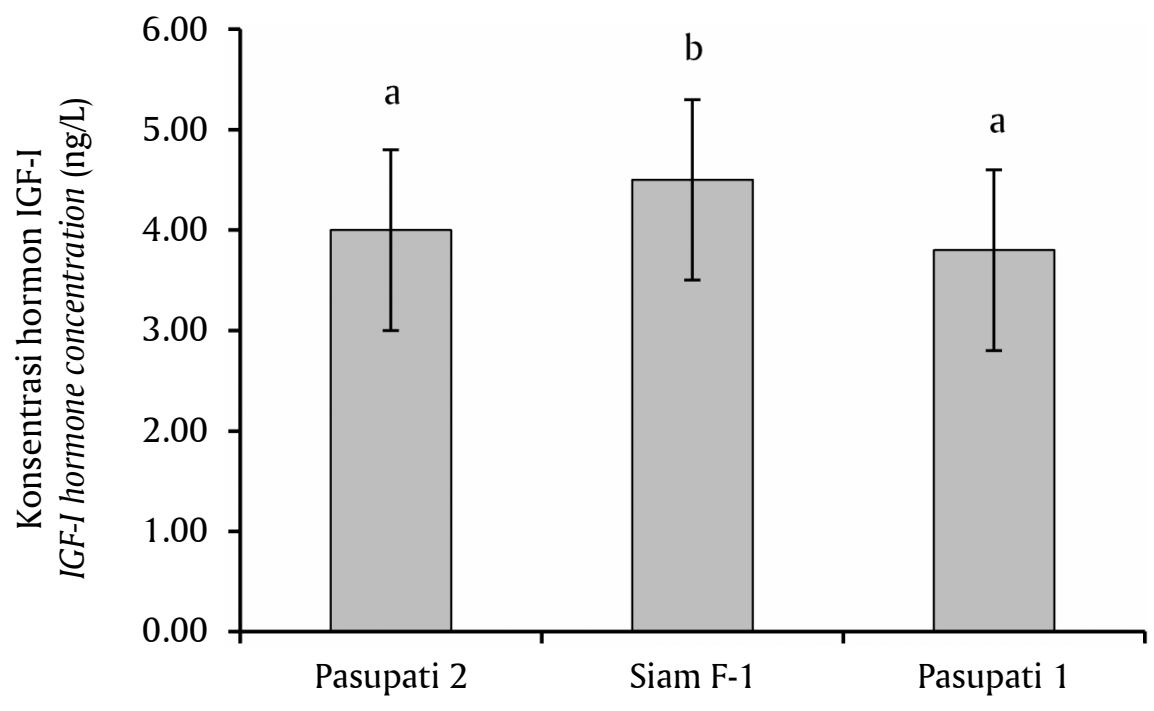

Gambar 1. Analisis kuantitatif hormon IGF-I pada plasma ikan patin Pasupati $1(3,93 \pm 0,54 \mathrm{ng} / \mathrm{mL})$; Pasupati $2(3,96 \pm 0,51 \mathrm{ng} / \mathrm{mL})$; dan Siam F-1 $(4,48 \pm 0,81 \mathrm{ng} / \mathrm{mL})$ yang dipelihara di KAT. Vertical bars merupakan SD ( $\mathrm{n}=9$ ekor ikan) dan pengujian duplo

Figure 1. Quantitative analysis of the hormone IGF-I in plasma of Pasupati 1 $(3.93 \pm 0.54 \mathrm{ng} / \mathrm{mL})$; Pasupati $2(3.96 \pm 0.51 \mathrm{ng} / \mathrm{mL})$; and Siam F$1(4.48 \pm 0.81 \mathrm{ng} / \mathrm{mL})$ that are kept in freshwater concrete pond. Vertical bars are $S D(n=9$ fish) and duplicate testing 
Hasil analisis ELISA pada beberapa ikan uji yang dipelihara di kolam air tawar menunjukkan bahwa konsentrasi hormon IGF-I pada ikan patin Pasupati II $(3,96 \pm 0,51 \mathrm{ng} / \mathrm{mL})$ tidak berbeda nyata $(\mathrm{P}>0,05)$ dengan patin Pasupati I $(3,93 \pm 0,54 \mathrm{ng} / \mathrm{mL})$. Namun demikian konsentrasi hormon IGF-I pada ikan patin Siam F-1 paling tinggi $(4,48 \pm 0,81 \mathrm{ng} / \mathrm{mL})$ (Gambar 1). Hasil ini menunjukkan terdapat korelasi positif antara pertumbuhan dengan konsentrasi hormon IGFI pada ikan uji. Hal ini yang menyebabkan pertumbuhan ikan patin Pasupati tidak berbeda nyata $(P>0,05)$ dibandingkan Pasupati I. Sehingga pada penelitian ini pertumbuhan patin Siam F-1 lebih cepat jika dibandingkan dengan ikan patin Pasupati I dan Pasupati II. Menurut Ohlsson et al. (2009), konsentrasi hormon IGF-I yang tinggi akan merangsang sekresi hormon pertumbuhan $(\mathrm{GH})$. GH akan merangsang sintesis protein di otot sehingga mempercepat pertumbuhan.
Moriyama et al. (2004) juga menyatakan bahwa jumlah hormon pertumbuhan yang dihasilkan oleh kelenjar pituitari akan berpengaruh terhadap pertumbuhan; jika hormon pertumbuhan diproduksi dalam jumlah sedikit, maka pertumbuhan yang dihasilkan akan lambat, sebaliknya jika hormon pertumbuhan yang diproduksi banyak, maka pertumbuhan akan menjadi lebih cepat. Ekspresi gen IGF-I yang terkait kuat dengan kecepatan pertumbuhan telah dilaporkan oleh Moriyama \& Kawauchi (1990).

Kualitas air merupakan salah satu faktor yang memengaruhi pertumbuhan. Kandungan oksigen di KAT berkisar antara 0,1-11,4 (Tabel 3) dan di tambak antara 2,22-4,90 (Tabel 4). Nilai kandungan oksigen dengan range yang relatif rendah diduga menyebabkan pertumbuhan ikan uji (Pasupati II dan Pasupati I) tidak optimal. Parameter kualitas air lainnya masih dalam kisaran layak.

Tabel 3. Kualitas air pemeliharaan ketiga populasi ikan di kolam air tenang (KAT), diukur secara diurnal

Table 3. Water quality of freshwater ponds in the rearing of the three populations of catfish, diurnally measured

\begin{tabular}{lccc}
\hline \multirow{2}{*}{$\begin{array}{c}\text { Parameter kualitas air } \\
\text { Parameters of water quality }\end{array}$} & \multicolumn{3}{c}{ Perlakuan (Treatments ) } \\
\cline { 2 - 4 } & Siam F-1 & Pasupati I & Pasupati II \\
\hline Oksigen terlarut $($ Dissolve oxygen $)(\mathrm{mg} / \mathrm{L})$ & $0.2-8.3$ & $0.1-11.4$ & $0.5-9.0$ \\
Suhu (Temperature) $\left({ }^{\circ} \mathrm{C}\right)$ & $28.9-32.3$ & $29.2-32.4$ & $28.6-32.4$ \\
Konduktivitas (Conductivity) $(\mathrm{S} / \mathrm{cm})$ & $25.7-28.2$ & $26.1-29.8$ & $26.1-30.2$ \\
Kekeruhan (Turbidity) (NTU) & $21-159$ & $35-148$ & $30-160$ \\
$\mathrm{pH}$ & $6.27-9.80$ & $6.22-9.19$ & $6.49-9.76$ \\
$\mathrm{NO}_{2}($ Nitrite) $)(\mathrm{mg} / \mathrm{L})$ & $0.11-0.13$ & $0.10-0.16$ & $0.10-0.12$ \\
$\mathrm{TAN}^{(\mathrm{mg} / \mathrm{L})}$ & $0.27-0.61$ & $0.18-0.45$ & $0.56-0.75$ \\
\hline
\end{tabular}

Tabel 4. Kualitas air pemeliharaan ketiga populasi ikan di tambak, pengukuran pada pukul 09.00 dan 11.00

Table 4. Water quality of brackishwater ponds in the rearing of the three populations of catfish, measuring in at 09:00 and 11:00

\begin{tabular}{lccc}
\hline \multirow{2}{*}{$\begin{array}{c}\text { Parameter kualitas air } \\
\text { Parameters of water quality }\end{array}$} & \multicolumn{3}{c}{ Perlakuan (Treatments) } \\
\cline { 2 - 4 } & Siam F-1 & Pasupati I & Pasupati II \\
\hline Oksigen terlarut (Dissolve oxygen) $)(\mathrm{mg} / \mathrm{L})$ & $2.22-4.90$ & $2.22-4.90$ & $2.22-4.90$ \\
Suhu (Temperature) $\left({ }^{\circ} \mathrm{C}\right)$ & $27.7-32.2$ & $27.7-32.2$ & $27.7-32.2$ \\
Konduktivitas (Conductivity) $(\mathrm{S} / \mathrm{cm})$ & $0.6-99.0$ & $0.6-99.0$ & $0.6-99.0$ \\
Kekeruhan (Turbidity) (NTU) & $54-196$ & $54-196$ & $54-196$ \\
Salinitas (Salinity) (ppt) & $1-8$ & $1-8$ & $1-8$ \\
$\mathrm{pH}$ & $7.12-9.39$ & $7.12-9.39$ & $7.12-9.39$ \\
\hline
\end{tabular}




\section{KESIMPULAN}

Performa populasi ikan patin Siam F-1 pada karakter bobot memberikan yang terbaik $(\mathrm{P}<0,05)$ dibandingkan dengan populasi ikan patin Pasupati I dan Pasupati II yang dipelihara di KAT dan di TAP. Kemudian performa pertambahan bobot ikan patin Pasupati II lebih baik $(\mathrm{P}<0,05)$ daripada ikan patin Pasupati I yang dipelihara di TAP. Hasil analisis ELISA pada beberapa populasi ikan uji yang dipelihara di KAT menunjukkan bahwa konsentrasi hormon IGF-1 tertinggi terdapat pada ikan patin siam F-1 (4,48 \pm $0,81 \mathrm{ng} / \mathrm{mL}$ ), kemudian diikuti oleh patin Pasupati II $(3,96 \pm 0,51 \mathrm{ng} / \mathrm{mL})$ dan terendah pada ikan patin Pasupati I $(3,93 \pm 0,54 \mathrm{ng} / \mathrm{mL})$. Jika dicermati dari data pertumbuhan dan konsentrasi hormon IGF-1 ikan uji ternyata terdapat korelasi yang positif antara pertumbuhan bobot ikan dengan konsentrasi hormon IGF-1. Semakin tinggi tingkat pertumbuhan bobot ikan diikuti juga semakin tinggi konsentrasi hormon IGF-1 pada ikan uji.

\section{UCAPAN TERIMA KASIH}

Kegiatan penelitian ini dibiayai oleh DIPA Tahun Anggaran 2014 Balai Penelitian Pemuliaan Ikan Sukamandi. Ucapan terima kasih kami sampaikan kepada Saudara Ihsan Aulia, Kamlawi, Ahmad Suryana, Arsad Tirta Subangkit, dan Sudarto yang telah membantu dalam pelaksanaan kegiatan penelitian ini.

\section{DAFTAR ACUAN}

Ariyanto, D., \& Utami, R. (2006). Evaluasi laju pertumbuhan, keragaman genetik dan estimasi heterosis pada persilangan antar spesies ikan patin (Pangasius sp.). Jurnal Perikanan (J. Fish. Sci.), VIII(1), 81-86.

Bakos, J. (2001). Guidelines for broodstock management. LAAReC Technical Report No. 0011. Lao PDR. Vientiane, 28 pp.

Bartley, D.M. (2005). Status of the world's fishery genetic resources. The Role of Biotechnology, 57 March 2005, Villa Gualino, Turin. Italy, 9 pp.

Bartley, D.M., Rana, K., \& Immink, A.J. (2001). The use of inter-specific hybrids in acuaculture and fisheries. Reviews in Fish Biology and Fisheries, 10, 325-337.

Browman, M.W., \& Kramer, D.L. (1985). Pangasius sutchi (Pangasidae), an air-breathing catfish that uses the swimbladder as an accessory respiratory organ. Copeia, 4, 994-998

BSN. (2000). Produksi induk ikan patin siam (Pangasius hypophthalmus) kelas induk pokok (Parent Stock). SNI 01-6483.1-2000. Badan Standarisasi Nasional. Jakarta, 9 hlm.
Butler, A.A., \& LeRoith, D. (2001). Minireview: Tissue-specific versus generalized gene targeting of the IGF1 and IGF11r genes and their roles in insulin-like growth factor physiology. Endocrinology, 142, 1685-1688.

Boyd, C.E. (1990). Water quality in pond for aquaculture. Auburn University Press. Alabama, 482 pp.

Castell, J.D., \& Tiews, K. (1980). Report of the EIFAC, IUNS and ICES Working Group on the standardization of methodology in fish nutrition research. Hamburg, Germany. EIFAC Tech. Paper, 24 pp.

Fjalestad, K.T. (2005). Breeding strategis. In: Gjedrem, T. (Ed.), Selection and Breeding Program in Acuaculture. Springer. Netherlands, p. 145-158.

Gjedrem, T. (1993). International selective breeding programs: Constrains and future prospect. In: Main, K.L., \& Reynolds, E. (Eds.), Selective Breeding of Fishes in Asia and United States. Proceeding of a Workshop in Honolulu, Hawaii, 3-7 May 1993. p. 18-30.

Gustiano, R., \& Kristanto, A.H. (2007). Evaluation of hybridization between Pangasius djambal Bleeker, 1846 and Pangasianodon hypophthalmus (Sauvage, 1878): biometric characterization and growth analysis. Indonesian Aguaculture Journal, 2(1), 2733.

Gustiano, R., Arifin, O.Z., \& Nugroho, E. (2008). Perbaikan pertumbuhan ikan nila (Oreochromis niloticus) dengan seleksi famili. Media Akuakultur, 3(2), 98-106.

Hardjosubroto, W. (1994). Aplikasi pemuliabiakan ternak di lapangan. Gramedia Widiasarana Indonesia. Jakarta, $275 \mathrm{hlm}$.

Iswanto, B., \& Tahapari, E. (2011). Embriogenesis dan perkembangan larva patin hasil hibridisasi antara betina ikan patin Siam (Pangasianodon hypophthalmus Sauvage, 1878) dengan jantan ikan patin jambal (Pangasius djambal Bleeker, 1846) dan jantan patin nasutus (Pangasius nasutus Bleeker, 1863). J. Ris. Akuakultur, 6(2), 169-186.

Iswanto, B. (2011). Hibridisasi antara betina patin siam (Pangasianodon hypophthalmus Sauvage, 1878) dengan jantan patin nasutus (Pangasius nasutus Bleeker, 1863) dalam upaya meningkatkan produktivitas patin daging putih. Tesis. Universitas Brawijaya. Malang, $219 \mathrm{hlm}$.

Iswanto, B., \& Tahapari, E. (2015). Uji fertilisasi antara patin pasupati dengan patin siam (Pangasianodon hypophthalmus Sauvage, 1878) dan patin jambal (Pangasius djambal Bleeker, 1846) (Dalam proses publikasi).

Kapuscinski, A.R., \& Miller, L.M. (2007). Genetic guidelines for fisheries managemant. University of Minnesota Sea Grant Program. Minnesota, 116 pp. 
Levefre, S., Huong, D.T.T., Wang, T., Nguyen, T.P., \& Bayley, M. (2011). Hypoxia tolerance and partitioning of bimodal respiration in the striped catfish (Pangasianodon hypophthalmus). Comparative Biochemistry and Physiology Part A, 158, 207-214.

Listyowati, N., \& Ariyanto, D. (2007). Evaluasi pertumbuhan beberapa strain ikan nila pada lingkungan budidaya bersalinitas. Laporan akhir hasil penelitian 2007. Loka Riset Pemuliaan dan Teknologi Budidaya Perikanan Air Tawar. Sukamandi, $13 \mathrm{hlm}$.

LRPTBPAT. (2006). Dokumen usulan pelepasan patin hibrida. Loka Riset Pemuliaan dan Teknologi Budidaya Perikanan Air Tawar. Sukamandi, 14 hlm.

Lutz, C.G. (2001). Practical genetics for aquaculture. Fishing News Book. London, 252 pp.

Moriyama, S., Ayson, F.G., \& Kawauchi, H. (2004). Growth regulation by insulin-like growth factor-i in fish. Bioscience, Biotechnology and Biochemistry, 64, 1553-1562.

Moriyama, S., \& Kawauchi, H. (1990). Growth stimulation of juvenile salmonids by immersion in recombinant salmon growth hormone. Nippon Suisan Gakkaishi, 56, 31-34.

National Research Council (NRC). (1977). Nutrient requirement of warmwater fishes. National Academic Press. Washington D.C., 78 pp.

Ohlsson, C., Mohan, S., Sjogren, K., Tivesten, A., Isgaard, J. Isaksson, O., Jansson, J.O., \& Svensson, J. (2009). The role of liver-delivered insulin-like growth factor-I. Endocr. Rev., 30(5), 494-535.

Pamungkas, W., Darmawan, J., Nurlaela, I., \& Tahapari, E. (2012). Perakitan strain unggul patin daging putih: Seleksi ikan patin Siam F-1. Laporan Teknis akhir kegiatan Kementerian Kelautan dan Perikanan. BPPI. Sukamandi, $11 \mathrm{hlm}$.

Pierce, A.L., Shimizu, M., Beckman, B.R., Baker, D.M., \& Dickho, V.W.W. (2005). Time course of the GH/ IGF axis response to fasting and increased ration in Chinook salmon (Oncorhynchus tshawytscha). Gen. Comp. Endocrinol., 140, 192-202.

Pongthana, N. (2001). Aquaculture genetics research in Thailand. In: Gupta, M.V., \& Acosta, B.O. (Eds.), Fish genetics research in member countries and institutions of the international network on genetics in Aquaculture. ICLARM Conference Proceeding, 64 pp.

Shimizu, M., Swanson, P., \& Dickhoff, W.W. (1999). Fre and protein bound insulin-like growth faktorI (IGF-I) and IGF-binding proteins in plasma of coho salmon, Oncorhynchus kisutch. General and Comparative Endocrinology, 115, 398-405.

Sudarto. (1993). A review of the fish breeding research and practices in Indonesia. In: Main, K.L., \& Reynolds, E. (Eds.), Selective breeding of fishes in asia and united states. Proceeding of a workshop in Honolulu. Hawaii, 3-7 May 1993. p. 182-189.

Sutton, D.L., Stanley, J.G., \& Milley, W.W. (1981). Grass carp hybridization and observations of a grass carp $\mathrm{X}$ bighead carp. Journal of Aquatic Plant management, 19, 37-39.

Steel, R.G.D., \& Torrie, J.H. (1991). Prinsip dan prosedur statistika suatu pendekatan biometrik. PT Gramedia Pustaka Utama. Jakarta, 748 hlm.

Sularto, Wartono, H., \& Nurlaela, I. (2012). Perakitan strain unggul patin daging putih: Seleksi ikan patin Jambal F-1. Laporan teknis akhir kegiatan Kementerian Kelautan dan Perikanan. BPPI. Sukamandi, $10 \mathrm{hlm}$.

Tahapari, E., Iswanto, B., \& Sularto. (2007). Perkembangan ovari dan oosit ikan patin hasil persilangan antara patin siam betina (Pangasianodon hypophthalmus) dengan patin jambal jantan (Pangasius djambal). Aquacultura Indonesiana, 8(2), 73-80.

Tahapari, E. (2013). Pembesaran ikan patin (siam dan pasupati) pada media pemeliharaan berbeda. Prosiding Seminar Nasional Tahunan x Hasil Penelitian Kelautan dan Perikanan, Jilid I: Budidaya Perikanan. Jogjakarta, hlm. 1-5.

Tahapari, E., Darmawan, J., Dewi, R.R.S.P.S., Nurlaela, I., \& Pamungkas, W. (2014). Evaluasi performa ikan patin pasupati yang diperbaiki, persilangan antara hasil seleksi betina patin siam (Pangasianodon hypophthalmus Sauvage, 1878) F-1 dengan jantan patin jambal (Pangasius djambal Bleeker, 1846) F1 pada segmen pembenihan. Prosiding Forum Inovasi Teknologi Akuakultur, hlm, 761-769.

Tave, D. (1995). Selective breeding programmes for medium-sized fish farms. FAO Technical Paper, 122 pp. FAO ISBN : 92-5103740-X.

Waynarovich, E., \& Harvath, L. (1980). The artificial propagation of warm water fin fish. a manual for extensing FAO. Fish. Tech. Pop., 201 pp.

Winarlin, \& Gustiano, R. (2008). Uji banding pertumbuhan biomassa ikan nila (Oreochromis niloticus) seleksi dan non-seleksi di kolam dan danau. Laporan teknis Balai Riset Perikanan Budidaya Air Tawar. Bogor, $7 \mathrm{hlm}$. 